\title{
PERBANDINGAN SKALA NYERI PADA KURETASE ANTARA PEMBERIAN LIDOKAIN PARASERVIKAL DAN INTRASERVIKAL
}

\author{
Yudhistya Ngudi Insan Ksyatria, Heru Pradjatmo, Ova Emilia
}

\begin{abstract}
Background: Curettage is a gynecological diagnostic and therapeutic procedures. Curettage actions causing sensation of pain although the pain threshold is different for each person. Local anesthesia is an effective choice for various minor gynecological procedures. One of them is paracervical block. Paracervical block reduces pain by blocking nerve impulses across the uterovaginal plexus. Another method is the injection of local anesthetic trough intracervical who works as an anesthetic infiltrating agent, distending the tissue, causing mechanical disruption of nerve impulses. Theoritically, intracervical lidocaine injection will require a lower level of precision than the blockade of peripheral nerves directly, more reliable and reproducible. We measured patient's pain during curettage using the Visual Analogue Scale (VAS).

Method: RCT

Location of study: Bantul District Hospital, Wonosari District Hospital, and Banjarnegara Distric Hospital. Result and Discussion: The study included 60 patients who got curettage within inclusion criteria. Every time patients came, we performed randomization and divided the patients into two groups, the control group (paracervical) and intervention group (intracervical), 30 subjects each. VAS was measured 5 minute after curettage was started. Characteristics of subjects in curettage frequency, curettage indication, parity and educational level for both groups are equal, did not differ statistically. The results of the mean pain scale (VAS). In the control group was $42,33 \pm 16,583$ and $34,33 \pm 18,880$ on the treatment group. Mean difference was $8 \mathrm{~mm}$, with $95 \% \mathrm{Cl}-1.124$ to 17.124 and $p=0.408$. The difference was not significant statistically. The intracervical group has mild pain scale (VAS $<44 \mathrm{~mm}$ ) in 27 of 30 patient, compared to 15 of 30 patients in paracervical group. It result in Relative Risk (RR) of 1,532.

Conclusion: Intracervical lidocaine injection can be considered as an alternative local anesthetic on curettage. The average pain scale did not differ significantly with paracervical block. And both of it located in VAS $<44 \mathrm{~mm}$ (mild pain). Intracervical lidocaine injection even have RR=1,532 compared with paracervical block to produce mild pain scale (VAS $<44 \mathrm{~mm}$ ).
\end{abstract}

Keywords: curettage - paracervical - intracervical - VAS

\begin{abstract}
ABSTRAK
Latar Belakang: Kuretase adalah prosedur ginekologi diagnostik dan terapi. Tindakan kuretase menimbulkan sensasi rasa nyeri walaupun ambang nyeri pada setiap orang berbeda. Anestesi lokal adalah pilihan efektif berbagai prosedur ginekologi minor. Salah satunya adalah blok paraservikal. Blok paraservikal mengurangi nyeri dengan memblokade impuls saraf yang melintasi pleksus uterovaginal. Metode anestesi lokal lain adalah injeksi lidokain intraservikal yang bekerja sebagai agen anestesi infiltratif dengan merenggangkan jaringan, menyebabkan gangguan mekanis impuls saraf. Secara teori injeksi lidokain intraservikal akan membutuhkan tingkat presisi lebih rendah dibandingkan memblokade saraf perifer dan kemungkinan lebih dapat diandalkan dan diulangi setiap kali. Hal ini dapat kita ketahui dengan mengukur skala nyeri pada pasien kuretase. Skala nyeri diukur menggunakan Visual Analogue Scale (VAS).
\end{abstract}

Departemen Obstetri dan Ginekologi Fakultas Kedokteran Universitas Gadjah Mada/

RSUP Dr. Sardjito Yogyakarta 
Metode: $R C T$

Tempat penelitian: RSUD Bantul, RSUD Wonosari, dan RSUD Banjarnegara

Hasil dan Pembahasan: Penelitian melibatkan 60 pasien terindikasi kuretase yang masuk kriteria inklusi. Setiap kali pasien datang secara random dibagi dalam dua grup. Grup kontrol (paraservikal) dan grup intervensi (intraservikal) masing-masing 30 subyek. Penilaian VAS dilakukan 5 menit setelah kerokan pertama kuretase dimulai. Karakteristik subjek penelitian pada dua kelompok menunjukkan frekuensi kuretase, indikasi kuretase, paritas dan tingkat pendidikan setara, tidak berbeda secara statistik. Hasil analisis dengan independent $t$-test (membandingkan rerata skala nyeri), kelompok kontrol (paraservikal) memiliki rerata VAS $42,33 \pm 16,583$ dan kelompok perlakuan (intraservikal) memiliki rerata VAS 34,33 $\pm 18,880$. (95\% Cl -1,124 s/d 17,124 dan $\mathrm{p}=0,408$ ) perbedaan ini tidak bermakna secara statistik. Pasien kuretase dengan skala nyeri ringan (VAS $<44 \mathrm{~mm}$ ) pada kelompok intraservikal sebanyak 27 orang dibandingkan kelompok paraservikal sebanyak 15 orang dengan Relative Risk $(R R)=1,532$. Analisis $X^{2}$-test ini memiliki $p<0,05$ sehingga perbedaan ini bermakna secara statistik.

Kesimpulan: Injeksi antara kelompok perlakuan dan kelompok kontrol lidokain intraservikal dapat dipertimbangkan sebagai alternatif anestesi lokal pada kuretase. Skala nyeri rata-rata yang dihasilkan tidak berbeda signifikan dengan blok paraservikal yaitu berada di VAS $<44 \mathrm{~mm}$ (nyeri ringan). Tetapi blok intraservikal memiliki $R R=1,532$ dibanding blok paraservikal untuk menghasilkan skala nyeri ringan (VAS $<44 \mathrm{~mm}$ ).

Kata kunci: Kuretase - paraservikal - intraservikal - VAS

\section{PENDAHULUAN}

Dilatasi dan kuretase mengacu pada pelebaran leher rahim dan pengambilan bagian dari dinding rahim dan atau isi rahim oleh kerokan (kuretase). Ini adalah prosedur ginekologi diagnostik, terapi, maupun aborsi trimester pertama. ${ }^{1}$ Tindakan kuretase menimbulkan sensasi rasa nyeri walaupun ambang nyeri pada setiap orang berbeda. Anestesi umum merupakan teknik standar manajemen nyeri pada tindakan operasi, tetapi meningkatkan resiko kematian yang lebih besar dibandingkan dengan anestesi lokal. $^{2}$

Nyeri saat kuretase timbul akibat dilatasi serviks, rangsangan ostium uteri interna serviks, mobilisasi rahim, gesekan dinding rahim, dan reaksi kontraksi otot rahim. Rasa sakit dapat disebabkan oleh dilatasi serviks yang terlalu kuat atau intervensi terlalu cepat setelah blok paraservikal. Ambang nyeri bervariasi dan ketakutan serta kecemasan dapat meningkatkan rasa sakit. $^{3}$

Nyeri merupakan sebuah perasaan atau sensasi tidak nyaman yang menandakan adanya kerusakan sel dalam tubuh atau inflamasi (radang). Pada kuretase nyeri yang terjadi berhubungan dengan dilatasi serviks dan kuretase tajam. Blokade rasa nyeri dimaksudkan untuk mengurangi dan atau menghilangkan rasa nyeri. Beberapa penelitian menunjukkan bahwa meski blok paraservikal dilakukan pada tindakan kuretase, nyeri berat dikeluhkan pada $21,3 \%$ hingga $50 \%$ kasus. $^{4}$

Anestesi lokal adalah pilihan efektif untuk berbagai prosedur ginekologi minor. Salah satu yang mudah dilakukan adalah blok paraservikal. ${ }^{5}$ Blok paraservikal merupakan teknik anestesi lokal yang sudah digunakan lama pada tindakan ginekologi minor dan telah terbukti efektivitasnya pada operasi Manchester-Fothergill dan 
reparasi serviks. Blok paraservikal terbukti aman, sederhana, dan efektif untuk dilatasi dan kuretase, terutama pada wanita dengan kontraindikasi pemberian anestesi umum. Blok paraservikal efektif untuk menghilangkan nyeri yang ditimbulkan oleh pemasangan tenakulum ke serviks, tetapi hanya menawarkan sedikit penghilang nyeri yang ditimbulkan oleh kuretase. ${ }^{6}$ Blokade paraservikal memang mengurangi nyeri di dalam bagian inferior uterus dan serviks dengan memblokade impuls saraf yang melintasi pleksus uterovaginal, tetapi mungkin tidak efektif untuk nyeri pada bagian superior uterus yang memiliki inervasi berbeda. ${ }^{7}$

Blok intraservikal adalah tindakan penyuntikan agen ke dalam stroma serviks. Banyak teknik dengan spektrum yang bervariasi. ${ }^{8}$ Blokade intraservikal bekerja sebagai anestesi infiltratif dengan menyebabkan distensi jaringan, sehingga menghasilkan gangguan mekanis pada impuls neural. Secara teoritis, blockade ini akan memberikan teknik injeksi yang lebih nyaman daripada blokade saraf dan mungkin lebih dapat diandalkan. Hingga kini, masih ada perdebatan tentang efikasi dari metode intraservikal dan paraservikal dan masih sedikit data yang ada tentang teknik yang mampu memberikan analgesia terbaik. ${ }^{2}$

Visual Analogue Scale(VAS) adalah skala respon psikometrik yang dapat dipergunakan sebagai kuesioner. VAS adalah instrumen pengukuran terhadap hal subjektif yang tidak dapat diukur secara langsung. Ketika merespon VAS, responden menyebutkan level posisi pada sebuah garis dengan dua ujung. ${ }^{9}$

\section{Jenis dan Rancangan Penelitian}

Penelitian ini dilakukan secara eksperimental dengan uji klinik secara random (randomized controlled trial) dengan penyamaran ganda (double blind).
Penelitian ini dilakukan di RSUD Wonosari, Bantul dan Banjarnegara selama 3 bulan (November 2013-Januari 2014) yang bersedia mengikuti penelitian dan memenuhi kriteria inklusi. Populasi penelitian adalah semua pasien yang akan dilakukan tindakan kuretase. Subyek penelitian adalah bagian dari populasi penelitian yang memenuhi kriteria inklusi, menandatangani surat persetujuan tindakan, kemudian dilakukan randomisasi.

Kriteria inklusi pada penelitian ini adalah semua pasien yang akan dilakukan tindakan kuretase dan sudah menyetujui tindakan kuretase. Kriteria eksklusi adalah pasien menginginkan dan memerlukan anestesi umum, dalam keadaan emergensi sehingga tidak memungkinkan dilakukan anestesi lokal, dan mempunyai kontraindikasi serta riwayat alergi terhadap lidokain.

Jumlah sampel pada penelitian ini 60 subyek, dengan 30 subyek kelompok kontrol (mendapat injeksi lidokain paraservikal) dan 30 subyek kelompok intervensi (mendapat injeksi lidokain intraservikal).

Variabel bebas penelitian ini adalah teknik anestesi injeksi lidokain paraservikal dan injeksi lidokain intraservikal. Variabel tergantung adalah skala nyeri. Variabel luar adalah: usia, paritas, tingkat pendidikan, frekuensi kuretase, dan indikasi kuretase.

Injeksi lidokain paraservikal adalah anestesi lokal yang diberikan dalam bentuk infiltrasi injeksi lidokain paraservikal dengan menggunakan $8 \mathrm{ml}$ lidokain 1\% (2 ampul lidokain 2\% diencerkan dengan aqua menjadi $8 \mathrm{ml}$ ). Anestesi injeksi lidokain paraservikal diinjeksikan paraservikal melalui forniks pukul 4,5 7 dan 8 sedalam 0,5-1,5 $\mathrm{cm}$.

Injeksi lidokain intraservikal adalah anestesi lokal yang diberikan dalam bentuk infiltrasi injeksi lidokain intraservikal dengan menggunakan $8 \mathrm{ml}$ 
lidokain 1\% (2 ampul lidokain 2\% diencerkan dengan aqua menjadi $8 \mathrm{ml}$ ). Anestesi injeksi lidokain intraservikal diinjeksikan pada serviks pukul 12, 3, 6 dan 9 sedalam 1,5-3 cm.

Nyeri adalah perasaan sakit yang menimbulkan penderitaan. Skala nyeri diukur dengan Visual Analog Scale dicatat dalam skala milimeter.

\section{Uji Statistik dan Analisis Data}

Dalam penelitian ini T-test digunakan untuk membandingkan rata-rata antara dua perlakuan. Untuk tingkat kemaknaan digunakan Confidence Interval $95 \%$ dan nilai $p<0,05 . X^{2}$ test digunakan untuk membandingkan proporsi pada dua perlakuan.

Data yang sudah dihimpun dikelola dan dianalisis dengan bantuan program komputer pengolah statistik. Hasil yang didapatkan dianalisis dengan menggunakan program komputer.

\section{HASIL DAN PEMBAHASAN}

Data komparabilitas kedua kelompok secara lengkap dapat dilihat pada tabel 1 . Terlihat kedua kelompok mempunyai karakteristik umum yang setara dimana rerata umur, frekuensi kuretase, indikasi kuretase, paritas dan tingkat pendidikan pasien tidak ada perbedaan bermakna pada kedua kelompok penelitian ( $p>0,05)$.

Analisis bivariat digunakan untuk melihat perbandingan antara dua variabel yaitu variabel bebas dan variabel tergantung, serta variabel luar dengan variabel tergantung. Pada penelitian ini variabel bebas adalah teknik anestesi Injeksi lidokain Paraservikal dan Injeksi lidokain Intraservikal, sedangkan variabel tergantung adalah skala nyeri. Uji statistik yang digunakan untuk uji banding pada variabel bebas dan tergantung digunakan uji statistik independent t-test yang membandingkan rerata kedua grup. Hasil penelitian dapat dilihat pada tabel 2 .

TABEL 1. Komparabilitas kedua kelompok subyek penelitian

\begin{tabular}{lccc}
\hline \multicolumn{1}{c}{ Variabel } & $\begin{array}{c}\text { Kelompok Kontrol Injeksi } \\
\text { lidokain Paraservikal }\end{array}$ & $\begin{array}{c}\text { Kelompok Perlakuan Injeksi } \\
\text { lidokain Intraservikal }\end{array}$ & $\mathrm{p}$ \\
\hline Umur (tahun) & Mean \pm SD & Mean \pm SD & \\
\hline $\begin{array}{l}\text { Frekuensi kuretase } \\
\text { pertama kali }\end{array}$ & $33,50 \pm 10,217$ & $32,63 \pm 8,377$ & 0,222 \\
$>1$ kali & $26(86,7 \%)$ & $\mathrm{N}(\%)$ & 0,647 \\
\hline Indikasi kuretase & $26(86,7 \%)$ & $4(13,3 \%)$ & \\
Abortus inkomplet & & & 0,896 \\
Blighted ovum & $13(43,3 \%)$ & $14(46,7 \%)$ & \\
Retensi sisa plasenta & $5(16,7 \%)$ & $5(16,7 \%)$ & \\
Lain-lain (kuretase & $5(16,7 \%)$ & $3(10 \%)$ & \\
diagnostik, polip & $7(23,3 \%)$ & $8(26,7 \%)$ & \\
endometrium) & & & \\
\hline Paritas & & $13(43,3 \%)$ & \\
Belum pernah melahirkan & $11(36,7 \%)$ & $17(56,7 \%)$ & \\
Sudah pernah melahirkan & $19(63,3 \%)$ & $12(40 \%)$ & 0,219 \\
\hline Tingkat pendidikan, N (\%) & $16(53,3 \%)$ & $18(60 \%)$ & \\
SD-SMP (wajib belajar) & $14(46,7 \%)$ & & \\
SMA keatas & & & \\
\hline
\end{tabular}


TABEL 2. Perbandingan skala nyeri kedua kelompok penelitian

\begin{tabular}{lcccc}
\hline Kelompok Penelitian & $\begin{array}{c}\text { Rata-rata } \\
\text { skala nyeri }\end{array}$ & $\begin{array}{c}\Delta \text { Perbedaan } \\
\text { rerata }\end{array}$ & $95 \% \mathrm{Cl}$ & $P$ \\
\hline $\begin{array}{l}\text { Kelompok Kontrol } \\
\text { (Injeksi lidokain }\end{array}$ & $42,33 \pm 16,583$ & & & \\
$\begin{array}{l}\text { Paraservikal) } \\
\begin{array}{l}\text { Kelompok Perlakuan } \\
\text { (Injeksi lidokain }\end{array}\end{array}$ & $34,33 \pm 18,880$ & 8 & $-1,124-17,124$ & $0,408^{*}$ \\
Intraservikal) & & & & \\
\hline
\end{tabular}

TABEL 3. Analisis $x 2$ test Variabel independen (injeksi lidokain paraservikal, injeksi lidokain intraservikal) dengan Variabel dependen (Skala nyeri)

\begin{tabular}{lccccc}
\hline \multirow{2}{*}{ Variabel } & \multicolumn{2}{c}{ Rerata skala nyeri } & \multirow{2}{*}{ RR } & $95 \% \mathrm{Cl}$ & $\mathrm{P}$ \\
\cline { 2 - 3 } & $<45 \mathrm{~mm}$ & $\geq 45 \mathrm{~mm}$ & & & \\
\hline Injeksi lidokain & & & & & \\
Intraservikal & $23(76,7 \%)$ & $7(23,3 \%)$ & 1,532 & $1,019-2,307$ & 0,03 \\
Paraservikal & $15(50 \%)$ & $15(50 \%)$ & & & \\
\hline
\end{tabular}

Tabel 2 memperlihatkan skala nyeri pada kedua kelompok tidak terdapat perbedaan bermakna ( $p>0,05 ; p=0,408)$. Perbedaan ratarata antara kedua kelompok sebesar 8 dengan confidence interval $95 \%$ antara $-1,124$ sampai dengan 17,124. Nilai $p>0,05$ menunjukkan bahwa perbedaan rerata skala nyeri yang ada tidak bermakna antara kelompok pasien yang dilakukan kuretase yang diberikan Injeksi lidokain Paraservikal dan yang diberikan Injeksi lidokain Intraservikal. Tetapi, rerata keduanya memberikan selisih rata-rata skala nyeri 8 . Dimana rerata skala nyeri pada injeksi lidokain paraservikal (kontrol) lebih tinggi daripada rerata skala nyeri pada injeksi lidokain intraservikal (intervensi).

Rerata skala nyeri pada injeksi lidokain Paraservikal adalah 42,33. Sementara rerata skala nyeri pada injeksi lidokain Intraservikal adalah 34,33. Keduanya mewakili penafsiran nyeri ringan (mild pain). Sesuai pembagian cut of point dari VAS dalam milimeter $(\mathrm{mm})$ yang direkomendasikan adalah: tidak nyeri (0-4 mm), nyeri ringan $(5-44 \mathrm{~mm})$, nyeri moderat $(45-74 \mathrm{~mm})$ dan nyeri hebat (75-100 mm). VAS dinilai dengan kertas dan pensil, tidak diperlukan training selain kemampuan menuliskan skala nyeri pada lembar VAS. Skala yang sama dan konsisten diperlihatkan secara konsisten kepada semua pasien. ${ }^{10}$

Tabel 3 menggambarkan analisis $\mathrm{X}^{2}$ test antara cara injeksi dan skala nyeri yang dikategorikan menjadi dua yaitu (no pain-mild pain) setara dengan VAS 0-44mm dan moderate-severe pain setara dengan skala VAS $>44 \mathrm{~mm}$. ( $p<0,05$ yaitu $\mathrm{p}=0,30$ ). Injeksi Intraservikal memiliki Relative Risk 1,532 kali lipat untuk menghasilkan skala VAS $<44 \mathrm{~mm}$ (nyeri ringan) dibandingkan injeksi lidokain paraservikal. Hal ini sesuai dengan teori bahwa kemudahan untuk melakukan injeksi lidokain intraservikal. ${ }^{2}$

Tabel 3 menggambarkan analisis $X^{2}$ tes antara cara injeksi lidokain dan skala nyeri yang dikategorikan menjadi dua yaitu tujuan manajemen nyeri pada tindakan kuretase 
adalah mengurangi atau mengeliminasi nyeri dengan efek samping yang minimal. Tujuan dari penelitian ini adalah membandingkan intensitas nyeri antara anestesi injeksi lidokain paraservikal dibandingkan dengan injeksi lidokain intraservikal pada tindakan kuretase, diharapkan hasil penelitian ini dapat memberikan variasi pilihan dalam manajemen nyeri selama tindakan kuretase. Dari nilai rerata dan simpangan baku, serta proporsi komparabilitas kedua kelompok penelitian (tabel 2), tidak ada perbedaan bermakna. Berdasarkan data karakteristik tersebut, data dianggap setara dan layak dibandingkan.

Pada penelitian ini terlihat bahwa injeksi lidokain intraservikal mempunyai karakteristik skala nyeri lebih rendah dibandingkan dengan Injeksi lidokain Paraservikal. Rata-rata skala nyeri pada kelompok Injeksi lidokain Paraservikal sebesar 42,33 $\pm 16,583$ dan kelompok Injeksi lidokain Intraservikal sebesar 34,33 $\pm 18,880$. Terdapat selisih rata-rata $8 \mathrm{~mm}$, tetapi selisih ini tidak berbeda secara statistik. Dimana angka selisih yang dibutuhkan agar signifikan secara statistik adalah $16 \mathrm{~mm}^{2}$

Tetapi kedua rerata tersebut berada dikisaran $<45 \mathrm{~mm}$. sehingga baik injeksi lidokain paraservikal maupun intraservikal menghasilkan kenyamanan dalam kuretase, menggambarkan nyeri yang diderita pasien didalam kategori nyeri ringan (VAS $4 \mathrm{~s} / \mathrm{d} 44 \mathrm{~mm}$ ).

Jika skala nyeri digolongkan menjadi dua grup. Dengan grup pertama adalah VAS 0-44 mm dan grup kedua adalah VAS 45-100 mm. Dimana grup pertama mewakili skala nyeri: tidak nyeri dan nyeri ringan, sementara grup kedua mewakili nyeri moderat dan nyeri hebat. Maka terdapat perbedaan yang signifikan. Dengan $p=0,03$ ataupun $p<0,05$. Dengan Relative-Risk 1,532. Yang artinya injeksi lidokain intraservikal mampu menghasilkan skala nyeri ringan 1,532 kali lipat dibandingkan injeksi lidokain paraservikal.
Sehingga dapat disimpulkan walaupun secara statistik rerata VAS antara grup kontrol dan intervensi tidak berbeda secara signifikan (karena selisih hanya $8 \mathrm{~mm}$ ) tetapi secara klinis injeksi lidokain intraservikal mempunyai Oddratio 3,286 kali untuk menghasilkan skala nyeri $<44 \mathrm{~mm}$.

Hal ini penting, karena didalam review oleh Tangsiriwatthana,2013 dikatakan blok regional menurunkan risiko nyeri berat/severe dibandingkan placebo saat kuretase/intervensi uterus, tetapi tidak untuk semua nyeri.

Sepuluh studi sebelumnya membandingkan paraservikal blok dengan placebo dimana injeksi anestesi paraservikal menurunkan nyeri saat prosedur intervensi uterus dilakukan, tapi tidak menurunkan nyeri setelah prosedur intervensi uterus dibandingkan placebo (perbedaan rerata $0,74,95 \% \mathrm{Cl} 0,28 \mathrm{~s} / \mathrm{d} 1,19)$. Demikian juga saat sebelum intervensi. Yaitu saat pemasangan spekulum dan tenakulum tidak terdapat perbedaan nyeri yang bermakna antara blok paraservikal dengan placebo. ${ }^{11}$

Pada penelitian ini untuk variabel umur, frekuensi kuretase, indikasi kuretase, paritas, dan tingkat pendidikan tidak mempengaruhi skala nyeri. Kedua kelompok penelitian tidak ada perbedaan bermakna pada variabel tersebut ( $p$ $>0,05$ ).

\section{KESIMPULAN DAN SARAN}

Berdasarkan hasil penelitian dan pembahasan, penelitian ini dapat disimpulkan walaupun secara statistik rerata VAS antara grup kontrol dan intervensi tidak berbeda secara signifikan (karena selisih hanya $8 \mathrm{~mm}$, dan $\mathrm{p}>0,05$ ) tetapi secara analisis $x 2$ test injeksi lidokain intraservikal mempunyai Relative-Risk 1,532 kali untuk menghasilkan skala nyeri $<44 \mathrm{~mm}$ yang menggambarkan nyeri ringan. 
Injeksi lidokain intraservikal menurunkan intensitas nyeri bila dibandingkan dengan injeksi lidokain paraservikal. Terutama jika skala nyeri digolongkan sesuai kategori no pain-mild dan moderate-severe pain. Dengan $p=0.03(p<0,05)$.

Perbedaan penurunan skala nyeri antara kedua kelompok sebesar $8 \mathrm{~mm}$ dengan interval konfiden antara $-1,124 \mathrm{~s} / \mathrm{d} \quad 17,124$ dengan $p=0,408$ yang berarti secara rata-rata skala nyeri perbedaan ini tidak bermakna secara statistik. Karena selisih skala VAS hanya $8 \mathrm{~mm}$. Dimana pada skala VAS dibutuhkan penurunan skala sebanyak $16 \mathrm{~mm}$ untuk dapat dianggap memberikan perbedaan yang bermakna.

Injeksi lidokain intraservikal dapat dipertimbangkan sebagai alternatif anestesi lokal pada tindakan kuretase. Skala nyeri yang dihasilkan berada di rata-rata $<44 \mathrm{~mm}$. sebanding dengan injeksi lidokain paraservikal. Bahkan memiliki Relative-Risk 1,532 kali untuk mempunyai skala nyeri $<44 \mathrm{~mm}$ (nyeri ringan) dibandingkan injeksi lidokain paraservikal.

Pada penelitian ini penulis memasukkan semua indikasi kuretase, baik yang memerlukan dilatasi ataupun tidak, hal ini keterbatasan penulis dalam feasibilitas. Sebagai saran, untuk penelitian berikutnya dapat dilakukan perbandingan dengan menggunakan salah satu indikasi kuretase saja.

\section{DAFTAR PUSTAKA}

1. Hayden, M. Dilation and Curettage (D\&C) for dysfunctional uterine bleeding. Healthwise. WebMD. Retrieved 2012-04-01. 2006.
2. Mankowski, JL., Kingston, J., Moran, T., Nager, C.W., Lukacz, ES. Paracervical Compared with Intracervical Lidocaine for Suction Curettage. ACOG. 2009. 113: 1052-7.

3. Vekemans, M. Abortion Guideline. International Planned Parenthood Federation. New York. 2005.

4. Phittayawechwiwat, W., Thananta. Paracervical Block in Obstetrics and Gynecology. California Medicine. 2007. 420-423.

5. Nadelberg, R. Paracervical Block. Department of Anesthesia Newton-Wellesley Hospital. Newton. 2007.

6. Praagh, V. Povey, WG. Paracervical block anaesthesia in labour. Can Anaesth Soc J. May; 1996 (1493): 232-9.

7. Rattanachaiyanont, M., Leerasiri, P., Indavivadhana, S. Effectiveness of Intrauterine Anesthesia for Pain Relief During Fractional Curettage. American College of Obstetricians and Gynecologists. Lippincott Williams \& Wilkins. 2005. 533-539.

8. Munro, MG. Uterine Anesthesia in Office Setting. Kaiser Permanente, Los Angeles Medical Center. 2008.

9. Reips UD, Funke F. Interval level measurement with visual analogue scales in Internet-based research: VAS Generator. BRM. 40(3), 2008. 699-704.

10. Hawker GA, Mian S, Kendzerska T, French M. Measures of Adult Pain. Arthritis Care and Research: Vol. 63, 2011. No. S11: pp. S240-S252.

11. Tangsiriwatthana T, Sangkomkamhang US, Lumbiganon P, Laopaiboon M.. Paracervical local anaesthesia for cervical dilatation and uterine intervention (Review). The Cochrane Collaboration: John Wiley \& Sons, Ltd.Issue 9. 2013. 